\title{
PENERAPAN E-FILING DAN SOSIALISASI PERPAJAKAN TERHADAP KEPATUHAN SUKARELA WAJIB PAJAK
}

\author{
Rika Fitriah ${ }^{1}$, Enong Muiz ${ }^{2}$ \\ 1,2Universitas Muhammadiyah Prof.Dr.Hamka, Fitriahrika13@gmail.com; \\ Hemuiz1955@gmail.com
}

\begin{abstract}
ABSTRAK
Penelitian ini bertujuan untuk mengetahui penerapan e-Filing, pengetahuan perpajakan, sosialisasi perpajakan terhadap kepatuhan sukarela Wajib Pajak. Penelitian ini menggunakan metode eksplanasi. Seluruh Wajib Pajak orang pribadi yang mempunyai NPWP yang berada di Indonesia adalah anggota populasi dan hanya 50 responden yang menjadi sampel yang digunakan pada penelitian ini. Hasil Penelitian ini menunjukkan bahwa penerapan e-Filing berpengaruh positif secara parsial dan signifikan terhadap kepatuhan sukarela Wajib Pajak. Pengetahuan perpajakan berpengaruh positif secara parsial dan signifikan terhadap kepatuhan sukarela Wajib Pajak. Sosialisasi perpajakan berpengaruh positif secara parsial dan signifikan terhadap kepatuhan sukarela Wajib Pajak. Berdasarkan uji simultan menunjukkan bahwa penerapan e-Filing, pengetahuan perpajakan dan sosialisasi perpajakan berpengaruh positif serta signifikan terhadap variable kepatuhan sukarela Wajib. Hasil ini menunjukkan bahwa semakin baik penerapan e-Filing dan Sosialisasi perpajakan maka kepatuhan sukarela Wajib Pajak akan semakin meningkat. Peningkatan penerapan e-Filing dan Sosialisasi perusahaan mampu meningkatkan kepatuhan sukarela Wajib Pajak.

Kata Kunci : E-Filing, Pengetahuan Perpajakan, Sosialisasi Perpajakan, Kepatuhan Sukarela Wajib Pajak

ABSTRACT

This study aims to determine the application of e-Filing, tax knowledge, tax socialization on taxpayer voluntary compliance. This study uses an explanation method. All individual taxpayers who have NPWP in Indonesia are members of the population and only 50 respondents were the sample used in this study. The results of this study indicate that the application of e-Filing has a partial and significant positive effect on voluntary taxpayer compliance. Tax knowledge has a partial and significant positive effect on voluntary taxpayer compliance. Tax socialization has a partial and significant positive effect on voluntary taxpayer compliance. Based on the simultaneous test, it shows that the application of e-Filing, tax knowledge and tax socialization has a positive and significant effect on the compulsory voluntary compliance variable. These results indicate that the better the application of e-Filing and the socialization of taxation, the more taxpayers' voluntary compliance will increase. Increasing the application of e-Filing and company outreach can increase the voluntary compliance of taxpayers.
\end{abstract}

Keywords: E-Filing, Tax Knowledge, Tax Socialization, Taxpayer Voluntary Compliance

Naskah diterima : 18-04-2021, Naskah dipublikasikan : 30-04-2021

\section{PENDAHULUAN}

Pajak mempunyai peranan yang sangat penting dalam kehidupan bernegara, khususnya untuk kelangsungan sistem pemerintahan suatu Negara, karena penerimaan terbesar suatu Negara adalah pajak. Penerimaan Negara yang bersumber dari sektor pajak ini akan digunakan untuk pembiayaan umum dari segala kegiatan pemerintah bahkan menjadi salah satu tolok ukur dari keberhasilan suatu perekonomian Negara.

Undang Undang KUP Nomor 28 Tahun 2007 ditambah UU Nomor 16 Tahun 2009 Pasal 1 ayat 1 tentang Ketentuan Umum dan Perpajakan (KUP) mendefinisikan pajak yaitu sebagai suatu kontribusi wajib kepada negara yang terutang oleh orang pribadi atau badan yang bersifat memaksa berdasarkan Undang-Undang, dengan tidak mendapatkan imbalan secara langsung dan digunakan 


\section{JURNAL AKUNTANSI, Vol. 10, No. 1, April (2021)}

untuk keperluan negara bagi sebesar-besarnya kemakmuran rakyat. Penerimaan pajak akan mengalami peningkatan jika jumlah Wajib Pajak juga meningkat. Usaha memaksimalkan penerimaan pajak tidak dapat hanya mengandalkan peran dari Dirtjen Pajak maupun petugas pajak, tetapi dibutuhkan juga peran aktif dari para Wajib Pajak itu sendiri.

Berdasarkan data kementerian keuangan, penerimaan pajak tahun 2019 mencapai 86,5\%. Pencapaian penerimaan pajak tahun 2019 ini masih kurang baik dibandingkan tahun 2018, yaitu sebesar $92,24 \%$. Hasil pungutan pajak di negara kita pada masa sekarang ini menjadi sumber utama penerimaan negara yang kontribusinya diharapkan semakin meningkat setiap tahunnya. Namun pada kenyataannya, keinginan masyarakat untuk membayar pajak masih sangat rendah. Hanya sebagian saja yang merasa benar-benar rela membayar pajak dan merasa ikut bertanggung jawab membiayai pengeluaran negara. Kepatuhan Wajib Pajak merupakan pemenuhan kewajiban perpajakan yang dilakukan oleh pembayar pajak dalam rangka memberikan kontribusi bagi pembangunan negara yang diharapkan di dalam pemenuhannya dilakukan secara sukarela dan menyampaikan surat pemberitahuan tahunannya dengan benar dan lengkap.

Berdasarkan data yang diperoleh DJP Rasio penyampaian SPT menggunakan e-Filing tahun 2019 mencapai sebesar 96\%. Presentase penyampaian SPT menggunakan e-Filing ini meningkat dari tahun 2018 yaitu hanya sebesar 92,5\%. Dengan diterapkannya $e$-Filing, akan lebih memudahkan para Wajib Pajak untuk menunaikan kewajibannya dalam membayar pajak tanpa harus datang dan mengantri di Kantor-kantor Pelayanan Pajak sehingga dapat meminimalisir biaya dan waktu yang digunakan Wajib Pajak. Selain itu, data Surat Pemberitahuan (SPT) dapat dikirimkan kapan saja dan dimana saja, tidak tergantung pada jam kantor dan dapat dilakukan di hari libur yaitu selama 24 jam dalam 7 hari tanpa memberikannya ke Petugas Pajak .

Dengan adanya kemudahan untuk memenuhi kewajiban perpajakan diharapkan dapat meningkatkan kepatuhan sukarela Wajib Pajak. Hal ini sejalan dengan penelitian yang dilakukan oleh Nurlaela, L. (2018) mengenai penerapan e-Filing berpengaruh positif dan signifikan terhadap kepatuhan Wajib Pajak. Namun hal berbeda diungkapkan Handayani, K. R., \& Tambun, S. (2016) yang menyatakan penerapan sistem e-Filing tidak berpengaruh signifikan terhadap kepatuhan Wajib Pajak. Faktor yang mempengaruhi kepatuhan sukarela Wajib Pajak yaitu pengetahuan pajak Pengetahuan pajak adalah proses dimana Wajib Pajak mengetahui tentang peraturan perpajakan dan mengaplikasikannya untuk melakukan kewajiban perpajakan. Pengetahuan perpajakan yang dimiliki oleh Wajib Pajak merupakan hal yang paling mendasar yang harus dimiliki oleh Wajib Pajak karena tanpa adanya pengetahuan tentang pajak, maka sulit bagi Wajib Pajak dalam melaksanakan kewajiban perpajakannya dan Wajib Pajak tidak dapat menyerahkan SPT tepat waktu jika mereka tidak mengetahui kapan waktu jatuh tempo dalam penyerahan SPT. Dimana Wajib Pajak yang benar-benar paham, mereka akan mengetahui sanksi administrasi dan sanksi pidana yang berhubungan dengan SPT.

Pengetahuan Wajib Pajak mengenai aturan dan ketentuan perpajakan yang berlaku di Indonesia diharapkan dapat meningkatkan kepatuhan Wajib Pajak. Menurut Rahayu, D. P. (2019) Semakin memadai pengetahuan Wajib Pajak tentang perundang-undangan pajak maka akan semakin tinggi pula kepatuhan sukarela Wajib Pajak. Hal ini dibuktikan oleh Hasil penelitian Rahayu, D. P. (2019) yang menunjukkan bahwa pengetahuan perpajakan berpengaruh terhadap kepatuhan sukarela Wajib Pajak.. Diiringi dengan pembaharuan sistem pelaporan SPT dan pembayaran pajak secara online sejak tahun 2014 yaitu e-filing dan e-billing, Dirjen Pajak senantiasa berupaya keras memberikan informasi tersebut melalui penyuluhan atau sosialisasi agar semakin diketahui dan dimengerti oleh Wajib Pajak (Andinata, 2015). Apabila Wajib Pajak diberikan pemahaman yang baik dan benar melalui sosialisasi yang efektif seperti di media sosial, internet ataupun baliho, diharapkan dapat meningkatkan kepatuhan sukarela Wajib Pajak. Hasil penelitian yang dilakukan Setyorini, C. T. (2016) menunjukkan sosialisasi perpajakan memiliki pengaruh signifikan terhadap kepatuhan Wajib 
Pajak. Namun berbeda pada penelitian Winerungan, O. L. (2013) menemukan bahwa sosialisasi perpajakan tidak berpengaruh terhadap kepatuhan Wajib Pajak.

\section{KAJIAN LITERATUR}

Pajak

\section{Pengertian Pajak}

Definisi Pajak yang dikemukakan oleh Undang-Undang Perpajakan Pasal 1 No. 16 tahun 2009 Tentang Ketentuan Umum dan Tata Cara Perpajakan, yaitu : kontribusi Wajib Pajak kepada negara yang terutang oleh orang pribadi/badan yang bersifat memaksa berdasarkan Undang-undang dengan tidak mendapat timbal balik secara langsung dan digunakan untuk keperluan negara bagi sebesarbesarnya kemakmuran rakyat." Sedangkan Definisi pajak yang dikemukakan oleh Siti Resmi (2017:1) yaitu: Pajak sebagai suatu kewajiban menyerahkan sebagian dari kekayaan ke kas negara yang disebabkan suatu keadaan, kejadian, dan perbuatan yang memberikan kedudukan tertentu, tetapi bukan sebagai hukuman, menurut peraturan yang ditetapkan pemerintah serta dapat dipaksakan, tetapi tidak ada jasa timbal balik dari negara secara langsung untuk memelihara kesejahteraan secara umum. Menurut Mardiasmo (2016:3) mendefinisikan pajak sebagai berikut: pembayaran/iuran rakyat atau masyarakat kepada kas negara berdasarkan undang-undang atau peraturan yang berlaku (yang dapat dipaksa) dengan tidak mendapat jasa timbal (kontraprestasi) yang langsung dapat digunakan untuk membayar pengeluaran/anggaran umum negara.".

Berdasarkan tiga definisi pajak diatas, penulis menyimpulkan bahwa pajak adalah Pajak adalah kontribusi atau iuran wajib rakyat kepada negara yang dapat dipungut dan bersifat memaksa dengan sesuai ketentuan perpajakan yang berlaku di Indonesia, pajak yang disetorkan tidak ada kontraprestasi (imbalan) secara langsung, namun digunakan untuk membiayai kesejahteraan Bersama.

\section{Fungsi Pajak}

Pajak merupakan sumber penerimaan Negara yang ada dua fungsi pajak menurut Siti Resmi (2017:3) yaitu:

\section{Fungsi Budgetair (Sumber Keuangan Negara)}

Pajak merupakan salah satu sumber penerimaan pemerintah untuk membiayai pengeluaran, baik rutin maupun pembangunan, sebagai sumber keuangan negara, pemerintah berupaya memasukkan uang sebanyak-banyaknya untuk kas negara.

\section{Fungsi Regularend (Pengatur)}

Pajak sebagai alat untuk mengatur atau melaksanakan kebijakan pemerintah dalam bidang sosial dan ekonomi serta mencapai tujuantujuan tertentu di luar bidang keuangan.

\section{Sistem Pemungutan Pajak}

Sistem pemungutan pajak di Indonesia Mardiasmo (2016:9) adalah sebagai berikut:

\section{Official Assessment System}

Sistem pemungutan pajak yang memberi kewenangan kepada pemerintah (fiskus) untuk menentukan besarnya pajak yang terutang oleh wajib pajak.

\section{Self Assessment System}

Sistem pemungutan pajak yang memberi wewenang kepada wajib pajak untuk menentukan sendiri besarnya pajak yang terutang.

\section{With Holding System}

Suatu sistem pemungutan yang memberi wewenang kepada pihak ketiga (bukan fiskus dan bukan Wajib Pajak yang bersangkutan) untuk menentukan besarnya pajak yang terutang oleh Wajib Pajak. 


\section{Wajib Pajak Orang Pribadi}

Menurut Undang-Undang No.16 Tahun 2009 tentang Perubahan Ketiga atas Undang-Undang No.6 Tahun 1983 tentang Ketentuan Umum Perpajakan, mendefinisikan wajib pajak sebagai berikut : Wajib Pajak adalah orang pribadi atau badan, meliputi pembayarpajak dan pemungut pajak yang mempunyai hak dan kewajibanperpajakan sesuai dengan ketentuan peraturan perundang-undangan perpajakan". Dalam penelitian ini ditujukan pada Wajib Pajak orang pribadi dalam negeri. Wajib pajak orang pribadi adalah Wajib Pajak yang telah memenuhi pesyaratan subjektif dan objektif sesuai dengan peraturan perundang-undangan di bidang perpajakan. Wajib Pajak yang telah memenuhi persyaratan wajib mendaftarakan diri secara langsung pada kantor pelayanan pajak dengan mengisi dan melampirkan persyaratan administrasi, kemudian Wajib Pajak diberikan Nomor Pokokyang Wajib Pajak (NPWP).

Subjek Pajak dalam Undang-undang Nomor 36 Tahun 2009 tentang Pajak Penghasilan adalah:

\section{Orang Pribadi}

Orang Pribadi sebagai subjek pajak bertempat tinggal atau berada di Indonesia maupun di luar Indonesia.

\section{Warisan}

Warisan yang belum terbagi sebagai satu kesatuan untuk menggantikan yang berhak yaitu ahli waris.

\section{Badan}

Pengertian Badan mengacu pada Undang-undang KUP, bahwa Badan adalah sekumpulan orang dan/ atau modal yang merupakan kesatuan baik yang melakukan usaha maupun yang tidak melakukan usaha yang meliputi Perseroan Terbatas (PT), Perseroan Komanditer (CV), perseroan lainnya, Badan Usaha Milik Negara (BUMN) atau Badan Usaha Milik Daerah (BUMD).

\section{Bentuk Usaha Tetap}

Bentuk usaha tetap adalah bentuk usaha yang dipergunakan oleh orang pribadi yang tidak bertempat tinggal di Indonesia, orang pribadi yang berada di Indonesia tidak lebih dari 183 hari dalam jangka waktu 12 bulan dan badan yang tidak didirikan dan tidak berkedudukan diIndonesia untuk menjalankan usaha atau melakukan kegiatan di Indonesia.

\section{Kepatuhan Wajib Pajak}

\section{Pengertian Kepatuhan Wajib Pajak}

Kepatuhan wajib pajak adalah sikap wajib pajak yang berusaha untuk mematuhi segala peraturan perpajakan dengan tanpa dipaksa (subekti, 2016). Sedangkan menurut Sufiah (2017) kepatuhan wajib pajak merupakan sikap wajib pajak dalam memenuhi kewajiban perpajakannya, yaitu wajib membayar pajak tepat waktu dan wajib melaporkan pajak tepat waktu. Menurut Rahayu (2017), Kriteria wajib pajak yang patuh sebagai berikut : 1). Tepat waktu dalam penyampaian Surat Pemberitahuan (SPT), 2). Tidak memiliki tunggakan pajak, 3). Tidak pernah dipidana terkait pelanggaran pajak. 


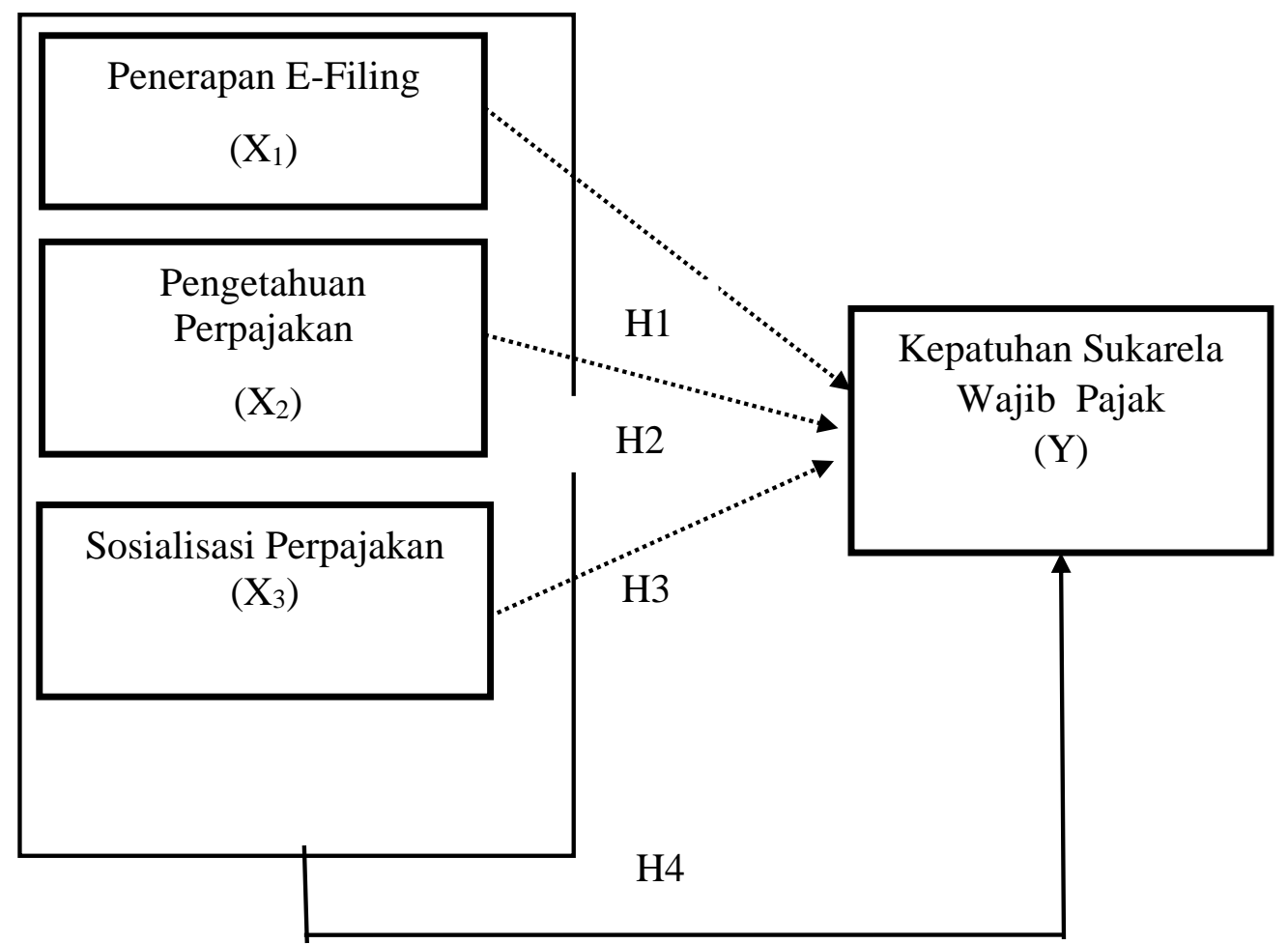

Gambar 1. Skema Kerangka Pemikiran Teoritis

Keterangan :

- - - Pengaruh masing-masing variabel independen terhadap variabel dependen.

$\longrightarrow$ : Pengaruh variabel independen secara simultan terhadap variabel dependen.

\section{Pengembangan Hipotesis}

Berdasarkan kerangka pemikiran di atas, maka dirumuskan hipotesis sebagai berikut :

$\mathrm{H}_{1}$ : Secara parsial Kesadaran Pajak berpengaruh positif terhadap Kepatuhan PajakSukarela Wajib Pajak.

$\mathrm{H}_{2}$ : Secara parsial Pengetahuan Pajak berpengaruh positif terhadap Kepatuhan Pajak Sukarela Wajib Pajak.

$\mathrm{H}_{3}$ : Secara parsial Religiusitas berpengaruh positif terhadap Kepatuhan Pajak Sukarela Wajib Pajak.

$\mathrm{H}_{4}$ : Secara simultan Kesadaran Pajak, Pengetahuan Pajak dan Religiusitas berpengaruh positif terhadap Kepatuhan Pajak Sukarela Wajib Pajak.

\section{METODOLOGI PENELITIAN}

\section{Metode Penelitian}

Metode penelitian yang digunakan dalam penelitian ini adalah Metode Eksplanasi. Data yang dianalisis dalam penelitian ini adalah data primer. yang menggunakan metode survei, yaitu menggunakan kuesioner yang dibagikan kepada responden. Kuesioner atau daftar pertanyaan sudah dibuat sebelumnya berdasarkan indikator atau kriteria pada setiap variabel yang digunakan. Kuesioner tersebut disebarkan melalui google form.

Populasi dalam penelitian ini adalah Wajib Pajak yang memiliki NPWP dan sudah menggunakan e-Filing yang terdaftar di Jabodetabek. Pemilihan populasi tersebut karena Wajib Pajak tersebut pernah menggunakan e-Filing sehingga dapat dijadikan responden untuk mengetahui kepatuhan sukarela Wajib Pajak pada tahun 2020. Teknik pengambilan sampel dalam penelitian ini 
adalah dengan metode accidental sampling, yaitu teknik penentuan sampel berdasarkan kebetulan yaitu siapa saja yang secara kebetulan bertemu dengan peneliti dan dapat digunakan sebagai sampel bila dipandang orang kebetulan ditemui itu cocok sebagai sumber data .

Kriteria sampel pada penelitian ini yaitu :

1. Wajib Pajak yang terdaftar di Jabodetabek

2. Wajib Pajak yang mempunyai NPWP

3. Wajib Pajak yang sudah menggunakan e-Filing

Teknik pengolahan dan analisis data yang digunakan adalah analisis akuntansi, uji kualitas data, analisis regresi linier berganda, uji asumsi klasik, uji hipotesis, dan koefisien determinasi dengan menggunakan SPSS versi 20.

\section{PEMBAHASAN}

Penelitian ini dilakukan kepada Wajib Pajak yang mempunyai NPWP yang telah menggunakan e-Filing. Wajib Pajak adalah orang pribadi atau badan yang mempunyai hak dan kewajiban perpajakan sesuai dengan ketentuan dan peraturan perundang-undangan perpajakan. Data yang digunakan dalam penelitian ini diperoleh dari kuesioner yang disebarkan oleh peneliti secara online dengan menggunakan google form. Peneliti membutuhkan 50 responden untuk diolah dengan jumlah item pertanyaan X1 sebanyak 9 item pertanyaan, X2 sebanyak 10 item pertanyaan, X3 sebanyak 7 item pertanyaan dan Y sebanyak 7 item pertanyaan. Dengan total seluruhnya adalah 32 item pertanyaan

Tabel 1. Hasil Uji T Signifikansi

\begin{tabular}{|ll|l|l|}
\hline \multicolumn{2}{|c|}{ Coefficients $^{\boldsymbol{a}}$} \\
Model & & & \\
\hline 1 & (Constant) & T & Sig. \\
\hline & Penerapan E-Filing (X1) & 1.305 & .199 \\
& Pengetahuan Perpajakan (X2) & 2.215 & .032 \\
& Sosialisasi Perpajakan (X3) & 2.049 & .046 \\
& & 2.313 & .020 \\
\hline
\end{tabular}

Sumber : Output SPSS 20.0 yang diolah peneliti

1) Nilai $t_{\text {hitung }}$ untuk penerapan e-Filing $\left(\mathrm{X}_{1}\right)$ adalah sebesar 2,215 $>\mathrm{t}_{\text {tabel }}=2,012$ dengan taraf signifikansi sebesar $0,032<0,05$, maka dapat disimpulkan $\mathrm{H}_{1}$ diterima, yang berarti hasil uji hipotesis menunjukkan bahwa variabel penerapan e-Filing berpengaruh secara parsial terhadap variabel kepatuhan sukarela Wajib Pajak.

2) Nilai thitung untuk pengetahuan perpajakan $\left(X_{2}\right)$ adalah sebesar 2,049 $>t_{\text {tabel }}=2,012$ dengan taraf signifikansi sebesar $0,046<0,05$, maka dapat disimpulkan $\mathrm{H}_{2}$ diterima, yang artinya hasil uji hipotesis menunjukkan bahwa variabel pengetahuan perpajakan berpengaruh secara parsial terhadap variable kepatuhan sukarela Wajib Pajak.

3) Nilai $t_{\text {hitung }}$ untuk sosialisasi perpajakan $\left(X_{3}\right)$ adalah sebesar 2,313 $>t_{\text {tabel }}=2,012$ dengan taraf signifikansi sebesar $0,020<0,05$, maka dapat disimpulkan $\mathrm{H}_{3}$ diterima, yang artinya hasil uji hipotesis menunjukkan bahwa variabel sosialisasi perpajakan berpengaruh secara parsial terhadap variable kepatuhan sukarela Wajib Pajak.

\section{Uji statistik F}

Uji statistik $\mathrm{F}$ digunakan untuk mengetahui pengaruh semua variabel independen yang dimasukan dalam model regresi secara bersama-sama terhadap variabel dependen yang diuji pada tingkat signifikan 0,05 (Ghozali, I., 2016 : 97). Dengan kata lain, menguji apakah variable penerapan e-Filing, pengetahuan perpajakan dan sosialisasi perpajakan secara bersamaan atau simultan 
mempengaruhi variabel kepatuhan sukarela Wajib Pajak. Cara yang digunakan adalah dengan membandingkan nilai probabilitas ( $p$-value) dengan tingkat signifikansi yang digunakan sebesar 0,05 , jika $p$-value lebih kecil dari 0,05 maka dapat dikatakan bahwa variabel-variabel independen secara simultan mempunyai pengaruh signifikan terhadap variabel dependen, atau dengan membandingkan $\mathrm{F}_{\text {hitung }}$ dengan $\mathrm{F}_{\text {tabel }}$ pada taraf signifikansi $\alpha=5 \%$ dengan $\mathrm{dfl}=4-1$ dan df $2=50-4$, maka diperoleh nilai $\mathrm{F}_{\text {tabel }}=2.80$. Berikut ini disajikan hasil uji signifikansi simultan (uji $\mathrm{F}$ ) dengan menggunakan SPSS 20 pada tabel di bawah ini :

Tabel 2. Hasil Uji F Signifikansi

\begin{tabular}{|ll|lr|l|l|l|l|}
\hline \multicolumn{2}{|c|}{ ANOVA $^{\text {b }}$} \\
\hline \multicolumn{2}{|l|}{ Model } & $\begin{array}{l}\text { Sum } \\
\text { Squares }\end{array}$ & of & Df & Mean Square & F & Sig. \\
\hline 1 & Regression & 660.617 & 3 & 220.206 & 31.954 & $.000^{\mathrm{a}}$ \\
& Residual & 317.003 & 46 & 6.891 & & \\
& Total & 977.620 & 49 & & & \\
\hline
\end{tabular}

Sumber: Output SPSS 20.0

Secara simultan terhadap $\mathrm{Y}$ adalah sebesar $0,000<0,05$ dan nilai $\mathrm{F}$ hitung $>\mathrm{F}$ tabel $31.954>$ 2,80, sehingga dapat disimpulkan bahwa $\mathrm{H}_{4}$ diterima, yang artinya hasil uji hipotesis menunjukkan bahwa variabel penerapan $e$-Filing, pengetahuan perpajakan dan sosialisasi perpajakan berpengaruh secara simultan terhadap variabel kepatuhan sukarela Wajib Pajak.

\section{Koefisien Determinasi $\left(\mathbf{R}^{2}\right)$}

Koefisien determinasi $\left(\mathrm{R}^{2}\right)$ merupakan suatu nilai (nilai proporsi) yang mengukur seberapa besar kemampuan variabel-variabel bebas yang digunakan dalam persamaan regresi, dalam menerangkan variasi variabel tak bebas. Nilai koefisien determinasi berkisar antara 0 dan 1 . Nilai koefsien determinasi $R^{2}$ yang kecil (mendekati nol) berati kemampuan variabel-variabel bebas secara simultan dalam menerangkan variasi variabel tak bebas amat terbatas. Nilai koefisien determinasi $R^{2}$ yang mendekati satu berarti variabel-variabel bebas memberikan hampir semua informasi yang dibutuhkan untuk memprediksi variasi variabel terikat.

Tabel 3. Hasil Uji Koefisien Determinasi

\begin{tabular}{|c|c|c|c|c|}
\hline Model & $\mathrm{R}$ & R Square & $\begin{array}{l}\text { Adjusted } \\
\text { Square }\end{array}$ & $R \mid \begin{array}{l}\text { Std. Error of the } \\
\text { Estimate }\end{array}$ \\
\hline 1 & $.822^{\mathrm{a}}$ & 676 & .655 & 2.62514 \\
\hline
\end{tabular}

Sumber : Output SPSS 20.0

Berdasarkan tabel 26, nilai koefisien determinasi $R^{2}$ terletak pada kolom Adjusted $R$-Square. Diketahui nilai koefisien determinasi sebesar $R^{2}=0,655$, yang artinya adalah 65,5\% variabel dependen kepatuhan sukarela Wajib Pajak dijelaskan oleh variabel independen penerapan e-Filing, pengetahuan perpajakan dan sosialisasi perpajakan, dan sisanya sebesar $34,5 \%$ dijelaskan oleh variabel lain yang tidak diteliti.

Berikut merupakan interpretasi dari hasil pengujian hipotesis antara variabel independen yaitu penerapan $e$-Filing, pengetahuan perpajakan dan sosialisasi perpajakan dengan variabel dependennya yaitu kepatuhan sukarela Wajib Pajak: 


\section{Penerapan e-Filing terhadap Kepatuhan Sukarela Wajib Pajak}

Berdasarkan hasil pengujian hipotesis di atas, menyatakan bahwa variabel penerapan e-Filing berpengaruh positif secara parsial serta signifikan terhadap variabel kepatuhan sukarela Wajib Pajak, hal tersebut dibuktikan dengan tingkat signifikansinya sebesar $0,032<0,05$, sedangkan nilai $t_{\text {hitung }}$ sebesar 2,215 $>t_{\text {tabel }}=2,012$. Dengan demikian penerapan $e$-Filing berpengaruh secara parsial terhadap variabel kepatuhan sukarela Wajib Pajak.

\section{Pengetahuan perpajakan terhadap Kepatuhan Sukarela Wajib Pajak}

Berdasarkan hasil pengujian hipotesis di atas, menyatakan bahwa variabel pengetahuan perpajakan berpengaruh positif secara parsial serta signifikan terhadap variabel kepatuhan sukarela Wajib Pajak, hal tersebut dibuktikan dengan tingkat signifikansinya sebesar 0,046 < 0,005 , sedangkan nilai $t_{\text {hitung }}$ sebesar 2,049 $>t_{\text {tabel }}=2,012$. Dengan demikian variabel pengetahuan perpajakan berpengaruh secara parsial terhadap variabel kepatuhan sukarela Wajib Pajak. Hasil peneltian ini didukung oleh penelitian Rahayu, D., P., (2019) yang menyatakan bahwa pengetahuan pajak memiliki pengaruh terhadap kepatuhan sukarela Wajib Pajak. Hal ini menunjukkan semakin tinggi pengetahuan perpajakan maka semakin tinggi pula tingkat kepatuhan sukarela Wajib Pajak.

\section{Sosialisasi Perpajakan terhadap Kepatuhan Sukarela Wajib Pajak \\ Berdasarkan hasil pengujian hipotesis di atas, menyatakan bahwa variabel sosialisasi perpajakan berpengaruh positif secara parsial serta signifikan terhadap variabel kepatuhan sukarela Wajib Pajak, hal tersebut dibuktikan dengan tingkat signifikansinya sebesar $0,020<$ 0,05 , sedangkan nilai $t_{\text {hitung }}$ sebesar 2,313 $>t_{\text {tabel }}=2,012$. Dengan demikian variabel sosialisasi perpajakan berpengaruh secara parsial terhadap variabel kepatuhan sukarela Wajib Pajak. \\ Hasil penelitian ini didukung oleh penelitian sebelumnya, yaitu penelitian Winerungan (2013) yang menujukkan bahwa sosialisasi perpajakan tidak berpengaruh signifikan terhadap kepatuhan sukarela Wajib Pajak.}

\section{Penerapan E-Filing, Pengetahuan Perpajakan dan Sosialisasi perpajakan terhadap Kepatuhan Sukarela Wajib Pajak}

Berdasarkan hasil pengujian hipotesis di atas, menyatakan bahwa variabel penerapan e-Filing, pengetahuan perpajakan dan sosialisasi perpajakan berpengaruh positif serta signifikan terhadap variabel kepatuhan sukarela Wajib Pajak. hal tersebut dibuktikan dengan tingkat signifikansinya sebesar $0,000<0,05$, dengan nilai $F_{\text {hitung }}$ sebesar $31.954>F_{\text {tabel }}$ sebesar 2,80 .

Hasil penelitian ini didukung oleh hasil penelitian Khasanah (2014) yang menyatakan bahwa pengetahuan perpajakan berpengaruh signifikan terhadap kepatuhan sukarela Wajib Pajak. Berdasarkan nilai Adjusted R Square sebesar 0,655 yang artinya adalah 65,5\% variabel dependen kepatuhan sukarela Wajib Pajak dijelaskan oleh variabel independen penerapan $e$ Filing, pengetahuan perpajakan dan sosialisasi perpajakan, dan sisanya sebesar $34,5 \%$ dijelaskan oleh variabel lain diluar variabel independen yang tidak di teliti.

\section{PENUTUP \\ Simpulan}

Berdasarkan metode eksplanasi yang digunakan pada penelitian ini menunjukkan bahwa semakin baik penerapan e-Filing dan Sosialisasi perpajakan maka kepatuhan sukarela Wajib Pajak akan semakin meningkat. Peningkatan penerapan e-Filing dan Sosialisasi perusahaan mampu meningkatkan kepatuhan sukarela Wajib Pajakbahwa penerapan e-Filing berpengaruh positif secara parsial dan signifikan terhadap kepatuhan sukarela Wajib Pajak. Pengetahuan perpajakan berpengaruh positif secara parsial dan signifikan terhadap kepatuhan sukarela Wajib Pajak. Sosialisasi perpajakan berpengaruh positif secara parsial dan signifikan terhadap kepatuhan sukarela Wajib Pajak. Berdasarkan uji simultan menunjukkan bahwa penerapan e-Filing, pengetahuan perpajakan dan sosialisasi perpajakan berpengaruh positif serta signifikan terhadap variable kepatuhan sukarela Wajib.. 


\section{Saran}

Berdasarkan hasil penelitian dan dengan adanya beberapa keterbatasan dalam penelitian ini, maka penulis memberikan beberapa saran yang diharapkan dapat bermanfaat bagi peneliti selanjutnya. Saran-saran yang diberikan penulis yaitu sebagai berikut :

Diharapkan pada KPP setempat untuk mengadakan sosialisasi tentang e-Filing yang sifatnya terbuka untuk umum dan memberikan pengarahan tentang manfaat $e$-Filing untuk lingkungan sekitar, supaya Wajib Pajak lebih patuh dalam melaksanakan kewajibannya. Diharapkan untuk penelitian selanjutnya dapat memperbesar atau menambahkan jumlah sampel dalam penelitian agar data yang dihasilkan dari penelitian selanjutnya lebih akurat.

\section{REFERENSI}

Andinata, M.C. 2015. Analisis Faktor Faktor Yang Mempengaruhi Kepatuhan Wajib Pajak Orang Pribadi Dalam Membayar Pajak (Studi Kasus Pada Kantor Pelayanan Pajak Pratama Rungkut Di Surabaya). Calyptra : Jurnal Ilmiah Mahasiswa Universitas Surabaya Vol. 4 No.2.

Gunadi. (2016). Panduan Komprehensif Ketentuan Umum Perpajakan (KUP). Jakarta: Bee Media Indonesia.

Handayani, K. R., \& Tambun, S. (2016). Pengaruh Penerapan Sistem E-Filing dan Pengetahuan Perpajakan terhadap Keptuhan Wajib Pajak dngan Sosialisasi sebagai Variabel Moderating. Media Akuntansi Perpajakan, Vol. 1, No. 2.

Khazanah, S. N. (2013). Pengaruh Pengetahuan Perpajakan, Modernisasi Sistem Administrasi Perpajakan, Dan Kesadaran Wajib Pajak Terhadap Kepatuhan Wajib Pajak Pada Kantor Wilayah Direktorat Jenderal Pajak Daerah Istimewa Yogyakarta. Yogyakarta: Fakultas Ekonomi Universitas Negeri Yogyakarta.

Mardiasmo. (2018). Perpajakan. Yogykarta: Andi.

Nurlaela, L. (2018). Pengaruh Penerapan E-Filing terhadap Kepatuhan Wajib Pajak Di KPP Pratama Garut. Jurnl Wahana Akuntansi, Vol. 02; No. 02.

Rahayu, D. P. (2019). Faktor-faktor yang mempengaruhi Kepatuhan Sukarela Wajib Pajak. Jurnal Akuntansi Indonesia.

Rahayu, S. K. (2017). Perpajakan Indonesia: Konsep dan Aspek Formal. Bandung: Rekayasa Sains.

Resmi, S. (2014). Perpajakan: Teori dan Kasus. Jakarta: Salemba Empat.

Setyorini, C. T. (2016). The Influence of Tax Knowledge, Managerial Benefit and Tax Socialization Toward Taxpayer's Willingness to Pay SME's Tax. Acta Universitas Danubius , 96-107.

Sufiah. 2017. Pengaruh Faktor Internal dan Faktor Eksternal pada Kepatuhan Wajib Pajak Orang Pribadi Di Kota Surabaya. jurnalmahasiswa.unesa.ac.id/index.php/jurnalakuntansi/article/download/.../15894

Subekti, S.A. 2016. Faktor-Faktor yang Berpengaruh terhadap Kepatuhan Wajib Pajak dengan Preferensi Risiko sebagai Variabel Pemoderasi (Studi Kasus pada Wajib Pajak Badan Hotel Di DIY). repository.umy.ac.

Winerungan. (2013). Sosialisasi Perpajakan, Pelayanan Fiskus dan Sanksi Perpajakan Terhadap Kepatuhan WPOP di KPP Manado da KPP Bitung. Jurnal EMBA, Vol.1; No.3.

Penetapan Peraturan Pemerintah Pengganti Undang-Undang Nomor 5 Tahun 2008 tentang Perubahan Keempat Atas Undang-Undang Nomor 6 Tahun 1983 tentang Ketentuan Umum dan Tata Cara Perpajakan Menjadi Undang-Undang

Peraturan Pajak Penghasilan 2009 - UU Nomor 36 Tahun 2008 